\title{
Who is more entrepreneurial? A comparative study of vocational and academic students
}

\author{
Arun Bhattacharyya and Narottam Kumar \\ Kautilya Entrepreneurship and Management Institute, \\ Jain University, Bangalore, India
}

\section{Vocational and academic students}

Received 26 June 2019 Revised 4 October 2019 Accepted 20 December 2019

\begin{abstract}
Purpose - Research in the context of an individual's choice of an entrepreneurial career has looked at effect of perceived self-efficacy (PSE), personality characteristics (PC) and subjective norms on entrepreneurial intentions (EIs). In contrast, the purpose of this paper is to compare these constructs across a vocational student (VC) group and an academic group (AC), in a supportive entrepreneurial ecosystem. It also includes $\mathrm{PC}$ of the individuals as a variable.

Design/methodology/approach - The analysis is based on a quantitative method followed by a qualitative approach to gain more insights in the study domain. It includes administration of a survey questionnaire and a round of unstructured interviews with select students.

Findings - Theorizing that there would be significant differences in PSE, PC and EIs between the two groups, the study demonstrates that for all the three variables, individuals opting for a vocational course exhibit significant difference as compared to an academic group. The results are significant when controlled for family business background and gender.

Originality/value - This paper has contributed to the academic literature in the entrepreneurship domain by differentiating the choice of an academic course prior to taking up a career in entrepreneurship and how it impacts entrepreneurial orientations. These interrelationships can further be extended into the domain of social media and networks, to draw interesting insights pertaining to how students get influenced by the social media in their choice of entrepreneurial career.
\end{abstract}

Keywords Students, Vocation, Academic, Perceived self-efficacy, Subjective norms,

Personality characteristics, Entrepreneurial intentions, Entrepreneurship

Paper type Research paper

\section{Introduction}

Entrepreneurship has largely been characterized in relation with the identification and exploration of business opportunities (Shane and Venkataraman, 2000; Davidsson and Honig, 2003; Geldhof et al., 2014). The authors generally agree that entrepreneurship involves understanding the bases of opportunities, how the processes of discovery, evaluation and exploitation of opportunities take place and who does them (as against who do not). However, a critical area that is being researched for a sufficient length of time is on the antecedents of entrepreneurial behavior and whether such behaviors are a result of

(C) Arun Bhattacharyya and Narottam Kumar. Published in Asia Pacific Journal of Innovation and Entrepreneurship. Published by Emerald Publishing Limited. This article is published under the Creative Commons Attribution (CC BY 4.0) licence. Anyone may reproduce, distribute, translate and create derivative works of this article (for both commercial and non-commercial purposes), subject to full attribution to the original publication and authors. The full terms of this licence may be seen at http://creativecommons.org/licences/by/4.0/legalcode 
APJIE 14,1

cognitions and/or emotions (Krueger, Reilly and Carsrud, 2000). Related research has looked at such factors as attitude toward entrepreneurship, self-efficacy or beliefs of the individual who wants to start up, cognitions toward enterprise creation, gender differences, cultural influences, situational aspects promoting entrepreneurship, locus of control and intention to start (Davidsson and Honig, 2003; Webb and Sheeran, 2006; Geldhof et al., 2014). Several studies have also looked at the context of students who aspire to pursue entrepreneurship, sometimes as an alternative career path to "working for someone else" (Peterman and Kennedy, 2003; Schlaegel and Koenig, 2014; Zollo et al., 2017). Krueger et al. (2000) further state that to understand the incidence of entrepreneurial behavior among current nonentrepreneurs (e.g. students), it is essential to assess the antecedents of such behavior, especially the intent to start-up, because the individual (mind) is central to entrepreneurship.

Research that has attempted to find the intentions of students to take up a career in entrepreneurship have largely looked at what variables affect the students' choice of such a career (Crant, 1996; Schlaegel and Koenig, 2014; Zollo et al., 2017). Such studies have primarily focused on graduate or post-graduate students from various institutions and their intentions to commence an entrepreneurial activity. Very scant research has tried to focus on how the choice of a particular academic program by a student can affect entrepreneurial intentions (EIs) and behavior. To bridge this gap, we focus on two different populations of students:

- one set pursuing a vocational program (e.g., a degree in fashion designing); and

- second set pursuing a traditional academic program (e.g., a degree in commerce), and compares key variables affecting performance of an entrepreneurial behavior across the two groups.

We chose to do a comparative study because we found that the aims of either type of institution are usually different. The goal of academic institutions is to focus on overall academic development of the students and provide them with a foundation on a broad domain of study, whereas vocational institutes tend to provide students with professional proficiencies and skills that are occupation specific (Benavot, 1983; Chen and Astor, 2011). These authors find that vocational curricula, as compared to an academic one, provide more practical-oriented training to the students. The study was all the more interesting as the groups were selected from reputed institutes in the entrepreneurial hub of India, Bangalore, which is witnessing the incidence of a large number of start-ups (Audretsch and Caiazza, 2016, Bala Subrahmanya, 2017). A question that was central to this study was whether a supportive entrepreneurial eco-system influenced choice of an academic program and whether it affected key entrepreneurial characteristics.

The purpose of this paper was, therefore, to understand and evaluate whether (and how) students enrolling in two different types of educational programs - vocational and academic differed in their entrepreneurial characteristics and orientations. In this regard, four constructs that find mention in a wide range of entrepreneurial research - perceived self-efficacy (PSE), personality characteristics $(\mathrm{PC})$, subjective norms (SN) and $\mathrm{EI}$ - were used to investigate the difference between the two sets of student groups. The study compares these constructs across students opting for a vocational program and an academic program, in a supportive entrepreneurial eco-system.

\section{Literature review and hypotheses development}

Research in entrepreneurship in the context of students' choice of a professional career or occupational goals has found that students' start-up intentions is significantly influenced by his/her attitude toward entrepreneurship that relies on factors internal (e.g. personal 
characteristics, risk-taking propensity and available or acquired skill sets) and external (e.g. Vocational and a supportive entrepreneurial eco-system) to the formation of the intention (Kirkley, 2017; Zollo et al., 2017). Krueger et al. (2000) have said that the potentiality of being an entrepreneur can be gauged by a student's expression of interest in demonstrating proentrepreneurship behaviors in his/her institution. Such students who are willing to or are interested to consider entrepreneurship as an alternate career have been termed as potential entrepreneurs or nascent entrepreneurs, with such interests having its roots in their younger days (Peterman and Kennedy, 2003). In such studies, family background, especially prior academic students business experiences within the family, has received attention from various scholars (Crant, 1996; Peterman and Kennedy, 2003), wherein it has been postulated that the value and extent of business influences affect the ward's intentions to exhibit entrepreneurial behavior (Shapero and Sokol, 1982).

The intention to embark on an entrepreneurial career and its actual behavioral outcome, starting-up, has several antecedent constructs and variables as is evident from a stream of literature (Bird, 1988; Drnovšek et al., 2010). Such variables include attitude toward entrepreneurship and perceived behavioral control (Ajzen, 1991), PSE (Bandura, 2002), SN (Laviolette et al., 2012), PC of the entrepreneur (Licht and Siegel, 2005) and EI (Engle et al., 2012). Based on the prevalence of the constructs across studies, four of them have been used for the current study - PSE, SN, PC and EI. Although studies have argued how each of these actors affect $\mathrm{EI}$ and subsequent performance of the entrepreneurial act, the current study focus on the comparative analysis of these factors across the two student groups - vocational and academic. Each of the constructs is discussed in the next section, leading to corresponding hypotheses.

\section{Perceived self-efficacy}

According to some authors, a primary motivation influencing behavior of individuals, is prior beliefs (personal and shared) in one's capabilities in a particular domain and to organize and undertake specific actions to attain a desired outcome(s) (Bandura, 2002; Luszczynska et al., 2005). Authors have termed this as PSE and have argued that the construct is rooted in individual's competencies, cognitions, judgments about the self and action-orientation (Bandura, 2002). PSE not only influences the choice of activities and situations (e.g. a career) but also impacts the way individuals think about dealing with the efforts when the action is initiated (Cho and Lee, 2018). This is all the more pertinent because individuals have positive expectations of attaining the desired outcome(s) and the effort that they expend is proportional to the expectations envisaged (Prabhu et al., 2012).

PSE has been characterized in terms of their potentiality (e.g. high versus low) with researchers, for example, finding that individuals with higher PSE, (a) choose more challenging goals and (b) exhibit more determination to pursue those goals, than individuals with lower PSE (Luszczynska et al, 2005). It can, therefore, be argued that individuals with relatively higher PSE are likely to have stronger intentions in attaining the pre-determined goal such as starting-up. A factor that seems to be an integral part of self-efficacy literature is that PSE can be situation specific, that is, individuals believe that they have control over the situations and environment that lead to the attainment of desired outcomes (Bandura, 2002).

In entrepreneurship research, PSE is rooted in the socio-cognitive approach and has been positively related to the belief that one can start a new venture and successfully run it, despite the constraints faced in achieving the goal (Chen et al., 1998; Zhao et al., 2005; Antoncic et al., 2016). PSE in entrepreneurship, thus, refers to the potentiality of an individual's beliefs that (s)he is capable of undertake the roles and tasks of an entrepreneur in the domain chosen by him/her (Antoncic et al., 2016). Additionally, the individual's decision to engage in pre-determined entrepreneurial activities has been found to be affected 
APJIE 14,1

by environmental factors and the entrepreneur's ability to deal with these factors (Chen et al., 1998; Drnovšek, Wincent, and Cardon, 2010). Hence, PSE in the context of entrepreneurship can be thought of as the entrepreneur's belief that (s)he can strike a balance between his/her PC and the uncertainties of the environment (Drnovšek et al., 2010). An enhancement of PSE may lead to an increase in risk taking, through perceptive evaluations of opportunities and threats (Prabhu et al., 2000).

A line of research has also looked at the gender-PSE relationship to understand the differential effects of PSE on EIs for males and females (Wilson, Kickul, and Marlino, 2007). The authors found that males typically scored higher on PSE than females, whereas entrepreneurship education affected growth of PSE beliefs more for women. Judgments with respect to PSE, therefore, are likely to influence subsequent expectations of goal attainment through the strength of EIs and the possibility of the intentions to translate into actions such as starting-up (Laviolette et al., 2012). Research has furthermore found that PSE influences intentions to act and the corresponding action is itself influenced by the individual's traits, personality and experiences undergone by him/her throughout the life span (Antoncic et al., 2016). In this context, research has found that PSE is reactive to changes in personal context and can act as indicators of individual differences, such as choice of employment and career intentions (Zimmerman, 2000).

Vocational programs are more career - and occupation (e.g. fashion design) - oriented and are supposed to provide students with more specific inputs in terms of proficiencies and skills required for the particular profession (s)he is aspiring to embark on (Benavot, 1983; Chen and Astor, 2011). The goal of traditional academic institutions, as discussed earlier, is to focus on overall academic development of the students. Hence, we argue that students pursuing vocational programs are more likely to believe that they have a better chance of achieving their goals, because of the receipt of focused inputs on the career they want to choose; that is, they are likely to have a relatively higher sense of PSE, than those pursuing academic programs. We, therefore, hypothesize that:

H1. There will be significant difference in PSE for students pursuing vocational courses $\left(\mathrm{PSE}_{\mathrm{VC}}\right)$ than students pursuing academic courses ( $\left.\mathrm{PSE}_{\mathrm{AC}}\right)$. $\mathrm{PSE}_{\mathrm{VC}}$ will be significantly greater than $\mathrm{PSE}_{\mathrm{AC}}$.

\section{Personality characteristics}

A line of research in entrepreneurship has tried to understand why certain individuals start a business, whereas others do not under similar environments or conditions; that is, focus is on the person, and his/her personal values (Gartner, 1989; Licht and Siegel, 2005). This research on EIs and subsequent behavior has looked at the PC or attributes of individuals (e.g. gender, need for social recognition and childhood characteristics) who intend to take up entrepreneurship as an alternative career option (Geldhof et al., 2014; Farrukh et al., 2018), has exhibited competence to take up entrepreneurial activities or at least has a preference for such activities (SchmittRodermund, 2004). Webb and Sheeran (2006) find that motivations to achieve a goal (e.g. startingup) are dependent on the individual's ego and capability for conscious self-control. In other words, in this approach to the understand creation of new businesses, the entrepreneur is assumed to have certain internally-focused attributes that may have been embedded in him or her over the developmental years (Gartner, 1989). Such entrepreneurial motivations take into account individual-specific dimensions, such as need for approval, perceived meaning of wealth, social orientation, need for self-development and need to remain independent (Hayton, George and Zahra, 2002). Authors (Crant, 1996; Thompson, 2009) have argued that a proactive personality is 
likely to precede EIs, wherein the individual demonstrates initiative, has a bias toward action and exhibits perseverance in an effort to cause meaningful change in his/her environment.

The entrepreneurial personality has also been studied in conjunction with culture and researchers have tried to find association between individual personal attributes and local or national cultural values (Licht and Siegel, 2005). These studies have tried to find whether cultural orientations (e.g. collectivism versus individualism) can be linked with personality attributes of entrepreneurs, to shed light on individual entrepreneurial orientations. Research has also found that cultural values pertaining to a particular society incorporate the desirability dimension of that society to accept certain individual characteristics, such as risk taking (Hayton et al., 2002).

Taking these studies into account we argue that students of vocational programs will exhibit more positive inclination to start-up than academic program students. This is so because the specific content and nature (i.e. practice orientation) of the vocational programs is likely to enable the individual to be more proactive and biased toward action. For example, students in a fashion design program are likely to receive more fashion industryrelated inputs that maybe relevant to the current state of the fashion design industry. Frequent interactions with industry experts will help reinforce those beliefs about the self. Additionally, we can argue that students who have exhibited entrepreneurial behaviors in their childhood days and want to showcase such behaviors earlier than others are more likely to join vocational programs than academic programs. This leads us to our next hypothesis:

H2. There will be significant difference in $\mathrm{PC}$ for students pursuing vocational courses $\left(\mathrm{PC}_{\mathrm{VC}}\right)$ as compared to students pursuing academic courses $\left(\mathrm{PC}_{\mathrm{AC}}\right) . \mathrm{PC}_{\mathrm{VC}}$ will be significantly greater than $\mathrm{PC}_{\mathrm{AC}}$.

\section{Subjective norms}

Literature on behavioral intention has taken into account the role of $\mathrm{SN}$, described as the perceptions of (normative) influence provided by various social groups to which an individual belongs or comes in contact with, on the intention to execute a particular behavior (Shepherd and O'Keefe, 1984; Tarkiainen and Sundqvist, 2005). The authors generally agree that the degree to which the individual considers the influence to be (un)favorable is based on whether (s)he considers the other to be significant with respect to the behavior; that is beliefs based on normative influences consider the likelihood and expectations of (dis) approval by the significant others with respect to performance of the behavior in question (Shepherd and O'Keefe, 1984; Gentry and Calantone, 2002). The normative influence, however, may not be exerted in an explicit manner, but the individual is likely to experience it subjectively because (s)he considers it to be salient (Armitage and Conner, 2001; Rivis and Sheeran, 2003).

From an entrepreneurship context, authors (Laviolette et al., 2012) have postulated that SN represents a balance between the normative beliefs underlying considering entrepreneurship as a career choice and a motivation to conform to these normative beliefs. Although some authors have found that SN is a relatively weak predictor of EIs, because entrepreneurship may be more self-related and not a result of expectation of normative social influences, others have said that such norms can have a significant effect EIs (Armitage and Conner, 2001; Rivis and Sheeran, 2003).

A supportive entrepreneurship ecosystem has been found to foster positive EIs and behavior, wherein research has indicated the effect of geographically and culturally different locations on entrepreneurial behavior (Drnovšek et al., 2010). We argue that a thriving 
APJIE 14,1

entrepreneurial support system that enables individuals to perform the entrepreneurial act, as is the case with Bangalore from where our samples have been drawn, is likely to cause SN to have lesser effect on EIs and corresponding behaviors. The emergence of various small businesses in that ecosystem is likely to embolden the entrepreneurial aspirant and make him/her immune to a certain degree to normative influences imposed by the family and social groups considered significant by the individual. This, we argue, will be independent of the programs chosen by respective students. Hence, we hypothesize that:

H3. There will be no significant difference in $\mathrm{SN}$ between students pursuing vocational courses $\left(\mathrm{SN}_{\mathrm{VC}}\right)$ and students pursuing academic courses $\left(\mathrm{SN}_{\mathrm{AC}}\right)$.

\section{Entrepreneurial intentions}

A large body of research has considered EI as a key factor in entrepreneurship literature to understand why some individuals are able to see business opportunities and are willing to act upon them (Thompson, 2009; Valliere, 2015). EI has generally been described as the intention of an individual to start a new venture or create novel values in a venture that has already been started (Park, 2017). Intentions are supposed to be cognitively driven but are directed toward a specific achievable target with or without existing resources (Bird, 1988). Intentions also synthesize an individual's motivation to act, or not to act, in a certain manner that highlights his/her willingness to sustain that behavior (Chatzisarantis and Biddle, 1998; Rivis and Sheeran, 2003). In this context, authors (Shapero and Sokol, 1982; Prabhu et al., 2012) have suggested that intentions evolve from three factors - perceived desirability of choosing a particular option, propensity to act on one's own decisions and perceived feasibility of achieving the desired behavior.

In the entrepreneurship context, the intention to perform a desired behavior is likely to be affected by such factors as needs of the entrepreneurial aspirant, personal values and related beliefs and risk propensity toward business (Thompson, 2009). Because an entrepreneurial aspirant is located in a social setting, his/her personal need for achievement (McCelelland, 1961) and social contexts become significant in the formation of EI (Bird, 1988). This notion is supported by authors who have found that entrepreneurship is an uncertain activity and hence social norms (e.g. familial or peer-related) have a significant impact on EI (Carr and Sequeira, 2007; Engle et al., 2012, Schlaegel and Koenig, 2014). EI, therefore, is composed of three important features: it is dependent on the entrepreneurial aspirant's perceptions toward engaging in entrepreneurial behavior and corresponding preferences; it is contingent on the individual's conscious (cognitive) inclination to act upon the opportunities pertaining to the desired behavior (e.g. starting up) and subsequent perceptions of control of the process and it relies on the self-confidence of the individual about the likelihood of actually starting up (Chatzisarantis and Biddle, 1998; Thompson, 2009).

For students who aspire to be entrepreneurs, research has found several expectations of outcomes affecting EI:

- a sense of accomplishment;

- recognition by the intention by significant others;

- performance of a wide variety of activities to foster that intention; and

- expectation of rewards from the act (Valliere, 2015).

We argue that students opting for a vocational program, such as fashion design, do so with a precise purpose in mind - to gain specific knowledge and inputs that would reinforce their intention to become an entrepreneur and give them a sense of achieving something specific 
to further their entrepreneurial intent. They would be more likely, than students from academic programs, to exhibit an intention to embark on an entrepreneurial career and gain corresponding rewards for their choice. We, therefore, hypothesize that:

H4. There will be a significant difference in EI between students pursuing vocational courses $\left(\mathrm{EI}_{\mathrm{VC}}\right)$ and students pursuing academic courses $\left(\mathrm{EI}_{\mathrm{AC}}\right)$. $\mathrm{EI}_{\mathrm{VC}}$ will be significantly greater than $\mathrm{EI}_{\mathrm{AC}}$.
Vocational and academic students

\section{Methodology}

The study was designed to compare the four entrepreneurial characteristics- PSE, SN, PC and EI of students studying in a vocational program and those studying in an academic program; that is, it was designed to test the predictions put forward in $H 1$ to $H 4$. The study also aimed to find if there are significant differences across the groups controlled for the family business background and gender of the students pursuing the respective programs.

\section{Participants and design}

Participants in the study were students enrolled in two different types of undergraduate programs in two reputed colleges in Bangalore, India. Respondents for the vocational group (VC) were undergraduate students from a reputed fashion design institute in Bangalore, whereas those of academic group (AC) belonged to a reputed university in Bangalore that offered various academic programs. As qualification criteria for the study, the respondents were randomly selected from a larger pool of students who were enrolled for the respective programs. A total of 212 randomly selected respondents $(n=111$ for the VC and $n=101$ for the AC) completed the study (see Table I for details of the composition of the students). All participants were informed about the intent of the study prior to taking part in it. A one-way independent ANOVA, one-way independent ANCOVA and Pearson's correlation test were adopted for the data analysis.

\section{Procedure}

Participants from the vocational and academic institutions in Bangalore were randomly chosen from a pool of undergraduate students who had enrolled for the respective programs - fashion design for the vocational school and commerce degree for the academic school. The participants were administered a scale that had items that measured the four variables - PSE, SN, PC and EI. The scale had 21 questions that measured participants' scores on the four dimensions. Before administering the questionnaire, the participants were made to go through an entrepreneurial activity to sensitize them to the context of the study. For example, for the VC of students, an interaction was held with a young entrepreneur who had just launched her

\begin{tabular}{lccr}
\hline Description of item & Group "VC" & Group "AC" & \\
\hline No. of valid respondents & 111 & 101 & \\
Business family background & 66 & 58 & Table I. \\
Non-business family background & 45 & 43 & Description of \\
Male respondents & 20 & 48 & respondents for \\
Female respondents & 91 & PSE, SN, PC and EI & the study \\
Outcome measures & PSE, SN, PC and EI & \\
\hline
\end{tabular}


enterprise in Bangalore, whereas for the AC a case study of a "live" entrepreneur was 14,1 discussed.

\section{Measures}

Perceived self-efficacy

To measure PSE we used six items that the respondents rated on a seven-point Likert scale (1 = "extremely unsure", 2 = "very unsure", 3 = "slightly unsure", 4 = "neither sure not unsure", $5=$ "slightly sure", $6=$ "very sure" and $7=$ "extremely sure"). The respondents were asked to tick the option that reflected most accurately their response to questions such as "I believe I have the ability to deal with money matters in a professional manner" and "When I complete a project successfully, I immediately try to start another one." Items included in the scale were adapted from McGee et al. (2009) but refined based on the context of the study. Cronbach's alpha for the six-item measure was 0.81 . To capture overall PSE, the total score was calculated and used in the analysis.

\section{Subjective norms}

We developed a four-item measure to capture SN of the respondents. As part of the research design, we asked the respondents to indicate the number that in their opinion mirrored their response to such items as "The opinions of important others matter a lot to me" and "I am willing to borrow money from others. ...," (Krueger et al., 2000). This is in line with Ajzen (1991), wherein it has been highlighted that to understand the effect of SN on an individual, the item should include an aggregate measure similar to "What do important others think?" The focus of the questions was to understand whether the respondent preferred to take the suggestions and opinion of social others (e.g. family and friends) while deciding to embark on a career in entrepreneurship. As in the case of PSE, we used a seven-point Likert scale. Cronbach's alpha for this summative measure was 0.88 .

\section{Personality characteristics}

$\mathrm{PC}$ was measured by using a five-item scale that tried to understand the characteristics associated with (nascent) entrepreneurs (e.g. students). Items included such questions as, "I was/am a cautious youngster," and "I get easily bored." We used a seven-point Likert scale ( 1 = "never", 2 = "rarely", 3 = "sometimes", 4 = "once in a while", $5=$ "fairly often", $6=$ "often" and 7 = "always"). The reliability (Cronbach's alpha) across this measure was 0.71 .

\section{Entrepreneurial intention}

To capture the degree to which an individual intended to start a business, the respondents were asked to answer five questions. Example questions include, "I am willing to commit my savings to start a business" and "Changing my daily routine would be an important motivation for starting my own enterprise." We used pure intention measure to measure EI in accordance to Armitage and Conner (1991) and Thompson (2009). As with PC we used a seven-point Likert scale. Cronbach's alpha for this measure was 0.92 .

\section{Analysis, results and discussions}

This study was designed to test for the predictions of $H 1$ to $H 4$. The collected data was cleaned and tabulated systematically to include details of participants and outcome measures. We checked the collected data for normality and equality of variances. We found that data was normally distributed $(p>0.05$, Shapiro-Wilk test), and therefore parametric test (ANOVA, ANCOVA and Pearson's correlation) was used to analyze the data. 
A one-way independent ANOVA was used to analyze the four variables for both VC and $\mathrm{AC}$, followed by an ANCOVA to check the impact of family business background and gender as control variables. A correlation test was performed to observe the relationships between variables and to see whether each variable was measuring what it was supposed to measure and to rule out contaminations because of certain items. All statistical analysis was computed with two-tailed hypothesis. The results of variables studied for the two groups are detailed hereunder (Tables II, III and IV).

\section{Correlations}

We checked for correlations among the variables for both VC and AC using Pearson's correlation coefficient (see Table II for summary values). This was driven by the notion to observe whether the four variables had any relationships with one another and the magnitude of such relationships. For VC there was low correlation between SN and EI $(r$ $(111)=0.029, p>0.05)$, SN and PC $(r(111)=0.121, p>0.05)$, SN and PSE $(r(111)=0.171, p>$ $0.05)$, EI and PC $(r(111)=0.150, p>0.05)$, EI and PSE $(r(111)=0.236, p<0.05)$, and PC and PSE $(r(111)=0.098, p>0.05)$; only the correlation between EI and PSE was statistically significant. For AC, we found significantly low correlation between SN and EI $(r(101)=$ $-0.044, p>0.05)$, SN and PC $(r(101)=0.168, p>0.05)$, SN and PSE $(r(101)=0.123, p>0.05)$, EI and PC $(r(101)=0.134, p>0.05)$, EI and PSE $(r(101)=-0.037, p>0.05)$, and PC and PSE $(r(101)=-0.077, p>0.05)$. The results imply that each of the four variables separately define the entrepreneurial characteristics of the respondents for both the groups; the strength of relationships between them is low.

\section{H1 to H4}

One-way independent ANOVA was performed to check whether there is a statistically significant difference between the group means for the four variables - SN, PSE, PC and EI (see Table III for the results of ANOVA test). We found significant difference in PSE, PC and EI between the two groups. The typical statistics were: PSE $\left(M_{V C}=27.86, M_{A C}=24.03, F\right.$ $(1,210)=74.92, p<0.001), \mathrm{PC}\left(M_{V C}=22.66, M_{A C}=20.70, F(1,210)=16.44, p<0.001\right)$ and $\mathrm{EI}$ $\left(M_{V C}=22.04, M_{A C}=19.16, F(1,210)=82.48, p<0.001\right)$. As expected, we did not find any significant difference in the case of SN $\left(M_{V C}=18.07, M_{A C}=17.94, F(1,210)=0.07, p>0.05\right)$. The mean values for the variables of $\mathrm{VC}$ were, in general, higher than the mean values of the

\begin{tabular}{lcccccr}
\hline \multicolumn{3}{c}{ Descriptive statistics } & \multicolumn{3}{c}{ Correlation coefficients } \\
Variables & Mean & SD & SN & EI & PC & PSE \\
\hline Vocational group & & & & & \\
SN & 18.07 & 2.07 & & & \\
EI & 22.04 & 3.60 & 0.029 & & \\
PC & 22.66 & 3.70 & 0.121 & 0.150 & \\
PSE & 27.86 & 3.79 & 0.177 & $0.236^{*}$ & 0.098 & \\
Academic group & & & & & & \\
SN & 17.94 & 2.11 & & & \\
EI & 19.16 & 3.80 & -0.044 & & \\
PC & 20.70 & 4.85 & 0.168 & 0.134 & & \\
PSE & 24.03 & 3.67 & 0.123 & -0.037 & -0.077 & \\
& & & & &
\end{tabular}

Note: $* p<0.05$
Vocational and academic students 
APJIE

14,1

24

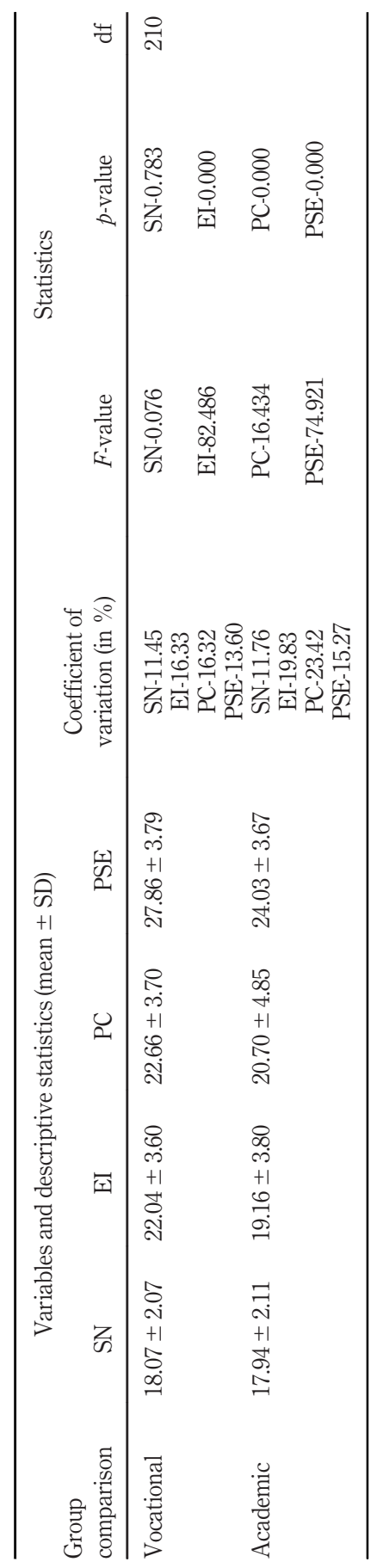

Table III.

Comparison chart of the analysis using one-way independent ANOVA 
$\mathrm{AC}$ (see Figure 1 for a comparison). We also used the coefficient of variation to understand the dispersion of variables around the mean in both the groups. We found that dispersion of data was higher in $\mathrm{AC}$ than that in $\mathrm{VC}$, but the dispersion was, in general, not very high (Table III).

\section{Control variables}

In line with existing studies on entrepreneurial characteristics (Laviolette et al., 2012), we used family background - business versus non-business - and gender as control variables. Respondents answered such questions as, "Did the choice of a particular program (i.e. vocational or academic) depend on whether individuals belonged to a family business group?" and "Does the family have a say in a student choosing a particular program?" A one-way ANCOVA was conducted to compare the entrepreneurial characteristics (four variables PSE, SN, PC and $\mathrm{EI}$ ) between the vocational and $\mathrm{AC}$ controlling for gender and family business background. The result showed that there was significant differences in PSE $(F(1,208)=64.92, p<0.001)$, EI $(F(1,208)=69.74, p<0.001)$ and PC $(F(1,208)=17.10$, $p<0.001)$ between the groups, implying that there is no impact of the control variables gender and family business background. We did not find any significant difference for SN $(F(1,208)=1.28, p<0.05)$ between the groups for both gender and family business background (see Table IV for the results of ANCOVA test). Typical $F$-statistics for variables with covariate gender: $\operatorname{PSE}(F(1,208)=0.00, p>0.05)$, EI $(F(1,208)=0.11, p>0.05)$, PC $(F(1,208)=1.41, p>0.05)$ and SN $F(1,208)=5.85, p<0.05)$. Typical $F$-statistics for variables with covariate family business background: $\operatorname{PSE}(F(1,208)=0.34, p>0.05)$, $\mathrm{EI}(F(1,208)=$ $1.82, p>0.05), \mathrm{PC}(F(1,208)=4.22, p<0.05)$ and $\mathrm{SN}(F(1,208)=0.18, p>0.05)$.

We had argued that PSE (H1), PC (H2), EI (H4) would be significantly higher for VCs than ACs. Our results show that there is a statistically significant difference in the means between the two groups for the three variables. We had further suggested that there would not be any statistical significant difference in SN H3) between the two groups. Our results support the prediction of this hypothesis. We thus find that $H H 1$ through 4 were supported.

We followed up the analysis with short discussions with some of the respondents to understand their choice of programs. Respondents with family business backgrounds, in general, indicated that the choice of the type of the program dependent on their inclination to start a new business, different form their existing line of business. As one respondent clarified (some others also echoed it!) "I want to work in a company for some years and gain some experience. This will help me choose a (different) business idea”. For respondents
Vocational and academic students

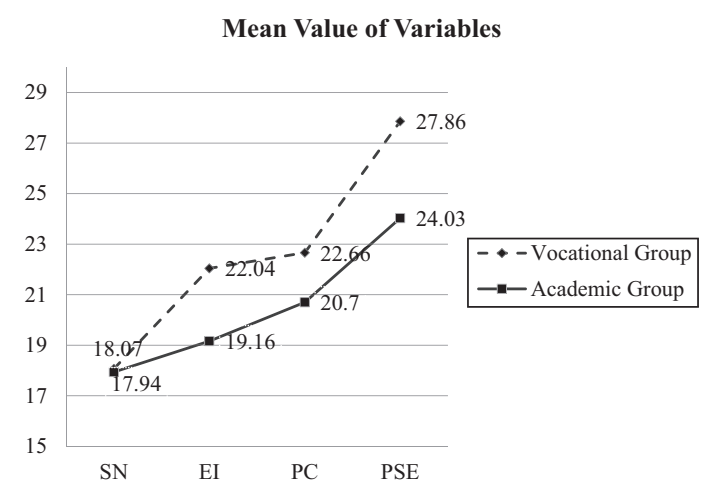

Figure 1.

Mean score of variables for students pursuing vocational program versus academic program 


\begin{tabular}{|c|c|c|c|c|c|c|c|}
\hline \multirow{2}{*}{$\begin{array}{l}\text { APJIE } \\
14,1\end{array}$} & \multirow[b]{2}{*}{$\begin{array}{l}\text { Variables } \\
\text { studied }\end{array}$} & \multirow[b]{2}{*}{$\begin{array}{l}\text { Mean and interval } \\
\text { estimate }\end{array}$} & \multicolumn{2}{|c|}{ Group } & \multirow[b]{2}{*}{$\begin{array}{l}\text { Source of } \\
\text { variation }\end{array}$} & \multicolumn{2}{|l|}{ Statistic } \\
\hline & & & Vocational & Academic & & $F$-value & $p$-value \\
\hline \multirow[b]{3}{*}{26} & \multirow[t]{2}{*}{ PSE } & Mean & 18.25 & 17.27 & Gender & 0.001 & 0.976 \\
\hline & & $95 \% \mathrm{CI}$ (LB to UB) & $17.64-18.87$ & 17.08-18.37 & Background & 0.347 & 0.557 \\
\hline & \multirow{3}{*}{ EI } & \multirow{3}{*}{$\begin{array}{l}\text { Mean } \\
95 \% \text { CI (LB to UB) }\end{array}$} & \multirow{3}{*}{$\begin{array}{l}22.01 \\
21.56-22.45\end{array}$} & \multirow{3}{*}{$\begin{array}{l}19.18 \\
18.71-19.65\end{array}$} & Group & 64.927 & $\begin{array}{l}0.000 \\
0.738\end{array}$ \\
\hline \multirow{8}{*}{$\begin{array}{l}\text { Table IV. } \\
\text { Comparison chart of } \\
\text { the analysis using } \\
\text { one-way ANCOVA }\end{array}$} & & & & & Background & 1.826 & 0.178 \\
\hline & & & & & Group & 69.744 & 0.000 \\
\hline & \multirow[t]{2}{*}{$\mathrm{PC}$} & \multirow{2}{*}{$\begin{array}{l}\text { Mean } \\
95 \% \text { CI (LB to UB) }\end{array}$} & \multirow{2}{*}{$\begin{array}{l}22.74 \\
22.06-23.41\end{array}$} & \multirow{2}{*}{$\begin{array}{l}20.62 \\
19.91-21.33\end{array}$} & Gender & 1.417 & 0.235 \\
\hline & & & & & $\begin{array}{l}\text { Background } \\
\text { Group }\end{array}$ & $\begin{array}{r}4.222 \\
17.103\end{array}$ & $\begin{array}{l}0.041 \\
0.000\end{array}$ \\
\hline & \multirow[t]{3}{*}{ SN } & Mean & 27.85 & 24.06 & Gender & 5.853 & 0.016 \\
\hline & & $95 \%$ CI (LB to UB) & $27.23-28.47$ & 23.41-24.71 & Background & 0.186 & 0.667 \\
\hline & & & & & Group & 1.289 & 0.257 \\
\hline & Notes: Cl & nfidence interval; LF & ound; UB: U & per bound & & & \\
\hline
\end{tabular}

without family business background, the choice of a program depended on "in what line" they want to start a business. One respondent who chose the fashion design program replied, "I saw and read about a lot of fashion start-ups in Bangalore and India and decided to join a fashion design course, so that I can start a boutique business." Another respondent who had joined the academic program replied that, "I know I would start something in the near future, but thought that I would complete my general education first." Further, female respondents when asked about their choice of programs pointed out that they needed approval from significant others (e.g. family or peers) before embarking on an entrepreneurial career.

\section{Conclusion}

PSE, SN, PC and entrepreneurial intentions have been linked with individuals aspiring to take up a career in entrepreneurship (Licht and Siegel; 2005, Engle et al., 2012). However, there is a dearth of literature that has studied an individual's choice of an academic course in an institute of repute, in terms of a vocation (s)he wants to pursue or a standard academic program that addresses the business scenario in general. This study has looked into an individual's choice of a particular program and its corresponding impact on the four variables in question, in a context and setting where starting up of new businesses has seen a steady rise. Although PSE, SN and entrepreneurial intentions have been studied as part of the theory of planned behavior (Ajzen, 1991), the current study brings in the construct of PC to gain more insights into the study.

\section{Theoretical contribution}

We have demonstrated that for PSE, PC and entrepreneurial intentions, individuals opting for a vocational course exhibit significant difference with those choosing a typical academic course. Through these findings, the study makes the following contributions to the literature. First, by collecting data and comparing across two groups of students who have opted for two different types of programs, the study has explored the orientation of entrepreneurial characteristics across these two groups. Second, this study takes into account the PC of students as a variable that affects 
entrepreneurial intentions and behavior, in addition to other three variables - PSE, entrepreneurial intentions and SN. To the best of our knowledge, this is the first study which takes into account all the four variables in the context of student's choice of a program of study. Third, the study controls for two very important characteristics in entrepreneurial literature - business background and gender.

\section{Practical implications}

The findings of this study have implications for academic institutions. Because the students opting for a VC are more entrepreneurial in nature, the curriculum design should be such that it reinforces the learning from that viewpoint. For example, the program design should incorporate more practice and experiential components (e.g. sessions by entrepreneurs and venture capitalists) to keep the students engaged so as to enable them to be more action oriented from an enterprise start-up perspective. Focus should also be on developing the entrepreneurial mindsets and attitudes of the students, especially females, so that they get motivated to consider entrepreneurship as a career. This is needed for the sustenance of the society at large, as creation of more entrepreneurs could lead to creation of more jobs.

\section{Limitations and scope for future research}

Certain limitations of the current study also provide directions for further research. First, this study has the typical restrictions that are associated with the choice of a particular (vocational or academic) group for the design of the research. Inclusion of populations' samples from other vocational or ACs would have thrown much richer insights and allowed for more generalizability of outcomes. Future studies can investigate the impact of other vocational and academic programs to add to the current body of knowledge. Second, although we tested across two types of programs, we could study the impact of various vocational programs (e.g. fashion design versus technology entrepreneurship versus food start-ups and so on), on the four variables. Third, we can use narratives from the respondents to understand the choice of particular programs and derive rich insights on the same. Narratives have been used extensively to understand life events of individuals that involve meaningful organization of selected events from the past and present day (McAdams, 2001).

The current research has shown that there are significant differences in PSE, PC and entrepreneurial intentions between students enrolled for vocational and academic programs. We believe that these interrelationships can be extended into the domain of social media and networks (e.g. Facebook) to draw interesting insights pertaining to how students get influenced by the social media in their choice of entrepreneurial career. For example, how does sharing of enterprise-specific knowledge and experiences take place on an on-line platform and what types of knowledge or experience get shared among the individual and others in the entrepreneurship domain.

\section{References}

Ajzen, I. (1991), "The theory of planned behavior", Organizational Behavior and Human Decision Processes, Vol. 50 No. 2, pp. 179-211.

Antoncic, B., Antoncic, J.A. and Aaltonen, H.M. (2016), "Marketing self-efficacy and firm creation", Journal of Small Business and Enterprise Development, Vol. 23 No. 1, pp. 90-104.

Armitage, C.J. and Conner, M. (2001), "Efficacy of the theory of planned behaviour: a meta-analytic review", British Journal of Social Psychology, Vol. 40 No. 4, pp. 471-499. 
APJIE 14,1

Audretsch, D. and Caiazza, R. (2016), "Technology transfer and entrepreneurship: cross-national analysis", The Journal of Technology Transfer, Vol. 41 No. 6, pp. 1247-1259.

Bala Subrahmanya, M.H. (2017), "Comparing the entrepreneurial ecosystems for technology startups in bangalore and hyderabad, India”, Technology Innovation Management Review, Vol. 7 No. 7 , pp. $47-62$.

Bandura, A. (2002), "Social cognitive theory in cultural context", Journal of Applied Psychology, Vol. 51 No. 2, pp. 269-290.

Benavot, A. (1983), “The rise and decline of vocational education”, Sociology of Education, Vol. 56 No. 2, pp. 63-76.

Bird, B. (1988), "Implementing entrepreneurial ideas: the case for intention", The Academy of Management Review, Vol. 13 No. 3, pp. 442-453.

Carr, J. and Sequeira, J. (2007), "Prior family business exposure as intergenerational influence and entrepreneurial intent: a theory of planned behavior approach", Journal of Business Research, Vol. 60 No. 10, pp. 1090-1101.

Chatzisarantis, N.L.D. and Biddle, S.J.H. (1998), "Functional significance of psychological variables that are included in the theory of planned behaviour: a self-determination theory approach to the study of attitudes, subjective norms, perceptions of control and intentions", European Journal of Social Psychology, Vol. 28 No. 3, pp. 303-322.

Chen, J.-K. and Astor, R.A. (2011), "School engagement, risky peers, and student-teacher relationships as mediators of school violence in taiwanese vocational versus academically oriented high schools”, Journal of Community Psychology, Vol. 39 No. 1, pp. 10-30.

Chen, C.C., Greene, P.G. and Crick, A. (1998), "Does entrepreneurial self-efficacy distinguish entrepreneurs from managers?”, Journal of Business Venturing, Vol. 13 No. 4, pp. 295-316.

Cho, Y. and Lee, J. (2018), "Entrepreneurial orientation, entrepreneurial education and performance", Asia Pacific Journal of Innovation and Entrepreneurship, Vol. 12 No. 2, pp. 124-134.

Crant, J.M. (1996), "The proactive personality scale as a predictor of entrepreneurial intentions", Journal of Small Business Management, Vol. 34 No. 3, pp. $42-49$.

Davidsson, P. and Honig, B. (2003), "The role of social and human capital among nascent entrepreneurs", Journal of Business Venturing, Vol. 18 No. 3, pp. 301-331.

Drnovšek, M., Wincent, J. and Cardon, M.S. (2010), "Entrepreneurial self-efficacy and business start-up: developing a multi-dimensional definition", International Journal of Entrepreneurial Behavior and Research, Vol. 16 No. 4, pp. 329-348.

Engle, R.L., Schlaegel, C. and Delanoe, S. (2012), "The role of social influence, culture, and gender on entrepreneurial intent", Journal of Small Business and Entrepreneurship, Vol. 24 No. 4, pp. 471-492.

Farrukh, M., Alzubi, Y., Shahzad, I., Waheed, A. and Kanwal, N. (2018), "Entrepreneurial intentions: the role of personality traits in perspective of theory of planned behaviour", Asia Pacific Journal of Innovation and Entrepreneurship, Vol. 12 No. 3, pp. 399-414.

Gartner, W.B. (1989), "Who Is an entrepreneur? is the wrong question”, Entrepreneurship Theory and Practice, Vol. 12 No. 4, pp. 47-67.

Geldhof, G.J., Weiner, M., Agans, J.P., Mueller, M.K. and Lerner, R.M. (2014), "Understanding entrepreneurial intent in late adolescence: the role of intentional self-regulation and innovation", Journal of Youth and Adolescence, Vol. 43 No. 1, pp. 81-91.

Gentry, L. and Calantone, R. (2002), "A comparison of three models to explain shop-bot use on the web”, Psychology and Marketing, Vol. 19 No. 11, pp. 945-956.

Hayton, J.C., George, G. and Zahra, S.A. (2002), "National culture and entrepreneurship: a review of behavioral research”, Entrepreneurship Theory and Practice, Vol. 26 No. 4, pp. 33-52. 
Kirkley, W. (2017), "Cultivating entrepreneurial behaviour: entrepreneurship education in secondary schools", Asia Pacific Journal of Innovation and Entrepreneurship, Vol. 11 No. 1, pp. 17-37.

Krueger, N.F., Reilly, M.D. and Carsrud, A.L. (2000), "Competing models of entrepreneurial intentions", Journal of Business Venturing, Vol. 15 Nos 5/6, pp. 411-432.

Vocational and academic students

Laviolette, E.M., Lefebvre, M.R. and Brunel, O. (2012), "The impact of story bound entrepreneurial role models on self-efficacy and entrepreneurial intention", International Journal of Entrepreneurial Behavior and Research, Vol. 18 No. 6, pp. 720-742.

Licht, A. and Siegel, J.I. (2005), "The social dimensions of entrepreneurship”, The Oxford Handbook of Entrepreneurship, doi: 10.1093/oxfordhb/9780199546992.003.0019.

Luszczynska, A., Scholz, U. and Schwarzer, R. (2005), "The general self-efficacy scale: multicultural validation studies", The Journal of Psychology, Vol. 139 No. 5, pp. 439-457.

McAdams, D.P. (2001), "The psychology of life stories", Review of General Psychology, Vol. 5 No. 2, pp. 100-122.

McGee, J.E., Peterson, M., Mueller, S.L. and Sequeira, J.M. (2009), "Entrepreneurial self-efficacy: refining the measure", Entrepreneurship Theory and Practice, Vol. 33 No. 40, pp. 965-988.

Park, C. (2017), "A study on effect of entrepreneurship on entrepreneurial intention”, Asia Pacific Journal of Innovation and Entrepreneurship, Vol. 11 No. 2, pp. 159-170.

Peterman, N.E. and Kennedy, J. (2s003), "Enterprise education: Influencing students' perceptions of entrepreneurship", Entrepreneurship Theory and Practice, Vol. 28 No. 2, pp. 129-144.

Prabhu, V.P., McGuire, S.J., Drost, E.A. and Kwong, K.K. (2012), "Proactive personality and entrepreneurial intent: is entrepreneurial self-efficacy a mediator or moderator?", International Journal of Entrepreneurial Behavior and Research, Vol. 18 No. 5, pp. 559-586.

Rivis, A. and Sheeran, P. (2003), "Descriptive norms as an additional predictor in the theory of planned behaviour: a Meta-Analysis", Current Psychology, Vol. 22 No. 3, pp. 218-233.

Schlaegel, C. and Koenig, M. (2014), "Determinants of entrepreneurial intent: a meta-analytic test and integration of competing models", Entrepreneurship Theory and Practice, Vol. 38 No. 2, pp. 291-332.

Schmitt-Rodermund, E. (2004), "Pathways to successful entrepreneurship: parenting, personality, early entrepreneurial competence, and interests", Journal of Vocational Behavior, Vol. 65 No. 3, pp. $498-518$.

Shane, S. and Venkataraman, S. (2000), "The promise of entrepreneurship as a field of research", Academy of Management Review, Vol. 25 No. 1, pp. 217-216.

Shapero, A. and Sokol, L. (1982), “The social dimensions of entrepreneurship,", In Kent, C.A. Sexton D. L.and Vesper K.H. (Eds), Encyclopedia of Entrepreneurship, Prentice Hall, Englewood Cliffs, NJ, pp. 72-90.

Shepherd, G.J. and O'Keefe, D.J. (1984), "Separability of attitudinal and normative influences on behavioral intentions in the Fishbein-Ajzen model", The Journal of Social Psychology, Vol. 122 No. 2, pp. 287-288.

Tarkiainen, A. and Sundqvist, S. (2005), "Subjective norms, attitudes and intentions of finnish consumers in buying organic food”, British Food Journal, Vol. 107 No. 11, pp. 808-822.

Thompson, E.R. (2009), "Individual entrepreneurial intent: construct clarification and development of an internationally reliable metric", Entrepreneurship Theory and Practice, Vol. 33 No. 3, pp. 669-694.

Valliere, D. (2015), "Purifying entrepreneurial intent: proposition of a new scale", Journal of Small Business and Entrepreneurship, Vol. 27 No. 5, pp. 451-470.

Webb, T.L. and Sheeran, P. (2006), "Does changing behavioral intentions engender behavior change? A meta-analysis of the experimental evidence", Psychological Bulletin, Vol. 132 No. 2, pp. 249-268.

Wilson, F., Kickul, J. and Marlino, D. (2007), "Gender, entrepreneurial self-efficacy, and entrepreneurial career intentions: implications for entrepreneurship education", Entrepreneurship Theory and Practice, Vol. 31 No. 3, pp. 387-406. 
APJIE

14,1

Zhao, H., Seibert, S.E. and Hills, G.E. (2005), "The mediating role of self-efficacy in the development of entrepreneurial intentions", Journal of Applied Psychology, Vol. 90 No. 6, pp. 1265-1272.

Zimmerman, B.J. (2000), "Self-Efficacy: an essential motive to learn", Contemporary Educational Psychology, Vol. 25 No. 1, pp. 82-91.

Zollo, L., Laudano, M.C., Ciappei, C. and Zampi, V. (2017), "Factors affecting universities' ability to foster students' entrepreneurial behavior: an empirical investigation", Journal of Management Development, Vol. 36 No. 2, pp. 268-285.

\section{Corresponding author}

Arun Bhattacharyya can be contacted at: b.arun@jainuniversity.ac.in

For instructions on how to order reprints of this article, please visit our website: www.emeraldgrouppublishing.com/licensing/reprints.htm

Or contact us for further details: permissions@emeraldinsight.com 